\title{
Stock assessment for the western winter-spring cohort of neon flying squid (Ommastrephes bartramii) using environmentally dependent surplus production models
}

\author{
Jintao Wang ${ }^{1,5}$, Wei Yu ${ }^{1,5}$, Xinjun Chen ${ }^{1,2,3,5}$, Yong Chen ${ }^{4,5}$ \\ ${ }^{1}$ College of Marine Sciences, Shanghai Ocean University, 999 Hucheng Ring Road, Lingang New City, Shanghai 201306, \\ China. E-mail: xjchen@ shou.edu.cn \\ ${ }^{2}$ National Engineering Research Centre for Oceanic Fisheries, Shanghai Ocean University, 999 Hucheng Ring Road, \\ Lingang New City, Shanghai 201306, China. \\ ${ }^{3}$ Key Laboratory of Sustainable Exploitation of Oceanic Fisheries Resources, Ministry of Education, Shanghai Ocean \\ University, 999 Hucheng Ring Road, Lingang New City, Shanghai 201306, China. \\ ${ }^{4}$ School of Marine Sciences, University of Maine, Orono, Maine 04469, USA. \\ ${ }^{5}$ Collaborative Innovation Centre for National Distant-water Fisheries, 999 Hucheng Ring Road, Lingang New City, \\ Shanghai 201306, China.
}

\begin{abstract}
Summary: The western winter-spring cohort of neon flying squid, Ommastrephes bartramii, is targeted by Chinese squidjigging fisheries in the northwest Pacific from August to November. Because this squid has a short lifespan and is an ecological opportunist, the dynamics of its stock is greatly influenced by the environmental conditions, which need to be considered in its assessment and management. In this study, an environmentally dependent surplus production (EDSP) model was developed to evaluate the stock dynamics of $O$. bartramii. Temporal variability of favourable spawning habitat with sea surface temperature (SST) of $21-25^{\circ} \mathrm{C}\left(P_{\mathrm{s}}\right)$ was assumed to influence carrying capacity $(K)$, while temporal variability in favourable feeding habitat areas with different SST ranges in different months $\left(P_{\mathrm{f}}\right)$ was assumed to influence intrinsic growth rate $(r)$. The parameters $K$ and $r$ in the EDSP model were thus assumed to be linked to temporal variability in the proportion of $P_{\mathrm{s}}$ and $P_{\mathrm{f}}$, respectively. According to Deviance Information Criterion values, the estimated EDSP model with $P_{\mathrm{s}}$ was considered to be better than the conventional surplus production model or other EDSP models. For this model, the maximum sustainable yield (MSY) varied from 210000 to $262500 \mathrm{t}$ and biomass at MSY level varied from 360000 to $450000 \mathrm{t}$. The fishing mortality rates of $O$. bartramii from 2003 to 2013 were much lower than the fishing mortality at target level and MSY level $\left(F_{t a r}\right.$ and $F_{\mathrm{MSY}}$ ) and stock biomass was higher than $B_{\mathrm{MSY}}$, suggesting that this squid was not in the status of overfishing and stock was not overfished. The management reference points in the EDSP model for $O$. bartramii were more conservative than those in the conventional model. This study suggests that the environmental conditions on the spawning grounds should be considered in squid stock assessment and management in the northwest Pacific Ocean.
\end{abstract}

Keywords: Ommartrephes bartramii; stock assessment; surplus production model; environmental factors; Northwest Pacific Ocean.

Evaluación de la cohorte occidental de invierno-primavera del calamar volador neon (Ommastrephes bartramii) utilizando modelos de producción excedente dependientes del medio ambiente

Resumen: La cohorte occidental de invierno-primavera de los calamares voladores neon, Ommastrephes bartramii, es objeto de las pesquerías chinas de calamares que operan con jigging en el Pacifico Noroeste, desde agosto a noviembre. Debido a que esta especie tiene un ciclo de vida corto y es ecológicamente oportunista, la dinámica de este stock de calamares está muy influenciada por las condiciones ambientales, las cuales necesitan ser consideradas en su evaluación y manejo. En este estudio fue desarrollado un modelo de producción excedente ambientalmente dependiente (PEAD), para evaluar la dinámica del stock de $O$. bartramii. Se asumió que la variabilidad temporal de un hábitat favorable para el desove sea a una temperatura superficial del mar de $21-25^{\circ} \mathrm{C}\left(P_{\mathrm{s}}\right)$, para influir en la capacidad de carga $(K)$; mientras que la variabilidad temporal en áreas con hábitat favorable para la alimentación, fue asumida con diferentes rangos de temperatura superficial del mar en diferentes meses $\left(P_{\mathrm{f}}\right)$, para influir la tasa intrínseca de crecimiento $(r)$. Los parámetros $K$ y $r$ en el modelo PEAD fueron asumidos como vinculados a la variabilidad temporal en la proporción $P_{\mathrm{s}}$ y $P_{\mathrm{f}}$, respectivamente. De acuerdo a los valores del Criterio de Información de la Desvianza, el modelo PEAD estimado con $P_{\mathrm{s}}$ fúe considerado el mejor, comparado con los modelos de producción excedente convencionales, así como otros modelos PEAD. Para este modelo el rendimiento máximo sostenible (RMS) estuvo entre 210000 a $262500 \mathrm{t}$ y la biomasa al nivel RMS, entre de 360000 a $450000 \mathrm{t}$. Las tasas de mortalidad por pesca de $O$. bartramii entre 2003 a 2013 fueron mucho menores que la mortalidad por pesca a nivel objetivo y nivel de RMS $\left(F_{\text {tar }}\right.$ and $\left.F_{\mathrm{RMS}}\right)$ y la biomasa del stock fue superior a $B_{\mathrm{RMS}}$, sugiriendo que este calamar no estuvo en el estado de sobrepesca y el stock no fue sobrepescado. Los puntos de referencia de manejo (PRMs) en el modelo PEAD para $O$. bartramii fueron más conservativos que aquéllos obtenidos en los modelos convencionales. Este estudio sugiere que las condiciones ambientales sobre las zonas de desove deberían ser consideradas en las evaluaciones y en el manejo de stock de calamares en el Océano Pacifico Noroeste. 
Palabras clave: Ommartrephes bartramii; evaluación de stock; modelo de producción excedente; factores ambientales; Océano Pacifico Noroeste.

Citation/Como citar este artículo: Wang J., Yu W., Chen X., Chen Y. 2016. Stock assessment for the western winter-spring cohort of neon flying squid (Ommastrephes bartramii) using environmentally dependent surplus production models. Sci. Mar. 80(1): 69-78. doi: http://dx.doi.org/10.3989/scimar.04205.11A

Editor: W. Norbis.

Received: January 7, 2015. Accepted: October 14, 2015. Published: December 14, 2015.

Copyright: (C) 2016 CSIC. This is an open-access article distributed under the Creative Commons Attribution-Non Commercial Lisence (by-nc) Spain 3.0.

\section{INTRODUCTION}

The neon flying squid, Ommastrephes bartramii, is an economically important oceanic species widely distributed in the northwest Pacific Ocean (Jereb and Roper 2010, Chen et al. 2008). This squid has been commercially exploited by Japanese squid-jigging fleets since 1974, and later by South Korea and Taiwan province of China. In 1993, the Chinese mainland squid-jigging fleets began exploratory fishing to investigate the abundance of $O$. bartramii in waters bounded by $38-42^{\circ} \mathrm{N}$ and $140-150^{\circ} \mathrm{E}$. In 1999 , several efforts further extended the fishing grounds eastward to $175^{\circ} \mathrm{W}$ (Wang and Chen 2005 , Chen et al. 2008). In general, Chinese squid-jigging vessels mainly fish in the regions between $170^{\circ} \mathrm{W}$ and $175^{\circ} \mathrm{W}$ in June and July, and then shift to waters west of $165^{\circ} \mathrm{E}$ from August to November (Wang and Chen 2005). The total annual production of squid caught by Chinese mainland ranged from 36764 to 113200 t from 2003 to 2013.

The North Pacific population of $O$. bartramii has been classified into four stocks: the central stock of the autumn cohort, the eastern stock of the autumn cohort, the western stock of the winter-spring cohort and the central-eastern stock of the winter-spring cohort (Bower and Ichii 2005). Of the four stocks, the western winter-spring cohort of $O$. bartramii has become a traditional fishing target for the Chinese squidjigging fleets in water between 150 and $165^{\circ} \mathrm{E}$ (Wang and Chen 2005). This cohort migrates from subtropical waters to the subarctic boundary during the first half of the summer and then moves northward into the subarctic domain from August to November. The squid mature gradually in autumn and are thought to begin their spawning migration in October and November (Murata and Nakamura 1998, Ichii et al. 2006).

Fishery biology, abundance and fishing ground distribution of $O$. bartramii have been well studied over the last few decades (Hayase 1995, Yatsu and Watanabe 1996, Yatsu and Mori 2000, Hikaru et al. 2004, Chen and Tian 2005, Wang and Chen 2005). Squid abundance and distribution are found to be significantly influenced by environmental conditions on the spawning and feeding grounds. For example, Chen et al. (2007) evaluated the sea surface temperature anomaly (SSTA) on the spawning and feeding grounds of $O$. bartramii, and concluded that high SSTA caused by La Niña events would lead to low recruitment, while the SSTA in an El Niño year tended to be normal and lead to high recruitment. Variability in the SST on the feeding ground could also result in different spatial distribution of the squid fishing ground. Cao et al. (2009) examined the variations in the proportion of thermal habitats with favourable sea surface temperature areas (PFSSTA) in 1995-2004, and suggested that PFSSTA in February on the spawning ground and from August to November on the feeding ground could explain about $60 \%$ of the variability in the abundance of $O$. bartramii. Additionally, Chen et al. (2011a) developed a habitat suitability index (HSI) model to identify the optimal habitat in relation to the oceanographic conditions, including sea surface temperature (SST), sea surface salinity (SSS), sea surface height anomaly (SSHA) and chlorophyll- $a$ (Chl- $a$ ) concentration. They found that the highest monthly catch and fishing effort occurring in the different waters were closely related to those variables.

Previous studies evaluated the annual stock size of the autumn cohort and winter-spring cohort of $O$. bartramii on the basis of catch data analyses (Chen et al. 2008, Ichii et al. 2006). Due to the unique life history of this species, traditional age- or length-structured models are not appropriate for evaluating the influences of intensive commercial jigging fleets on its stock dynamics. Many methods have been proposed for assessing short-lived species such as the squid. Ichii and Mahapatra (2004) evaluated the annual biomass of the autumn cohort in 1982-1992 on driftnet fishing grounds using a stock production model incorporating covariates (ASPIC non-equilibrium dynamic model) (Prager 1994) and the DeLury depletion model (Hilborn and Walters 1992). For the winter-spring cohort, Chen et al. (2008) fitted a modified depletion model to the Chinese squid-jigging fisheries data to estimate squid stock abundance in 2000-2005, and found that the annual maximum allowable catch ranged from 80000 to $100000 \mathrm{t}$, which was consistent with the estimation by Osako and Murata (1983) for the annual sustainable catch of the western stock. However, as a short-lived ecological opportunist, $O$. bartramii is also typically subject to large fluctuations in abundance, responding rapidly to changes in environmental conditions (Saito 1994, Hayase 1995, Bower 1996, Chen 1997, 1999, Bower and Ichii 2005, Chen and Tian 2005, Cao et al. 2009). Therefore, environmental variables are considered to play a critical role in regulating the dynamics of squid stocks and need to be considered in the squid stock assessment.

An environmentally dependent surplus production (EDSP) model has been developed from the traditional 
surplus production model. In surplus production models, fish population dynamics and fishing processes including natural mortality, growth, recruitment, and fishing mortality are assumed to be a function of a single aggregated measure of biomass (Zhan 1992). This approach may be suitable for species with a short-life span and/or limited availability of age/size composition data (Zhan 1992). Research has also shown that surplus production models, although simple, may provide more accurate and precise estimates of management-related quantities than complex models (Ludwing and Walters 1985, 1989). Therefore, a surplus production model incorporating environmental variables would be an appropriate approach for assessing the $O$. bartramii stock.

$O$. bartramii is a short-lived species with a lifespan of less than one year (Roper et al. 1984), whose yearly biomass is almost dependent on the recruitment (Yu et al. 2013). Thus, it is reasonable to consider the environmental indices in the assessment of the $O$. bartramii stock. However, the traditional surplus models treat the carrying capacity and intrinsic rate of growth as constant (Chen et al. 2008), which is inconsistent with the facts that carrying capacity and population growth rate for squid may fluctuate greatly over time as a result of changes in environmental condition on the spawning ground and feeding ground. In this study, we developed two environmental indicators including the proportions of the areas with favourable SST on the spawning ground $\left(P_{\mathrm{s}}\right)$ and feeding ground $\left(P_{\mathrm{f}}\right)$, which were assumed to influence carrying capacity $(K)$ and intrinsic growth rate $(r)$, respectively. We evaluated the traditional production models and several EDSP models with both indices, $P_{\mathrm{s}}$ only or $P_{\mathrm{f}}$ only, being incorporated. These models were compared and an optimal model was selected for estimating the squid stock abundance and reference points. This study may provide a new insight into the assessment of $O$. bartramii stock.

\section{MATERIALS AND METHODS}

\section{Fishery data}

Data on daily catch $(t)$, effort (days fished, $d$ ), fishing dates and fishing locations (longitude and latitude) were obtained from the Chinese mainland commercial jigging fleets operating in the areas between $35-45^{\circ} \mathrm{N}$ and $145-165^{\circ} \mathrm{E}$ in the northwest Pacific Ocean from July to December from 2003 to 2013 . The western stock of the winter-spring cohort and the central-eastern stock of the winter-spring cohort are separated near $170^{\circ} \mathrm{E}$ (Bower and Ichii 2005). Thus, the Chinese commercial jigging fleet should target a unit stock. One unit of fishing area was defined as $0.5^{\circ}$ latitude by $0.5^{\circ}$ longitude.

We assumed no by-catches in the squid fishery (Wang and Chen 2005), and there would be little discard relative to annual catches. Chinese jigging vessels, about 200 in number from 2003 to 2013, were equipped with an engine of $120 \mathrm{KW} \times 2,112 \mathrm{KW}$ squid attracting lights and 16 squid-jigging machines, and had almost identical fishing power and lighting operation. Therefore, catch per unit fishing day (CPUE, $\mathrm{t} \mathrm{d}^{-1}$ )

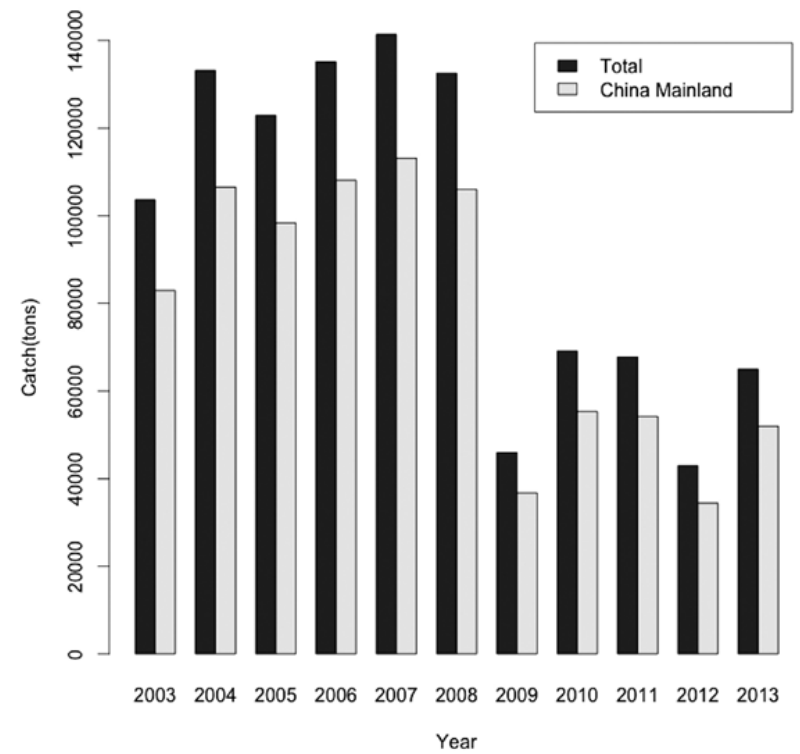

Fig. 1. - Annual total catch of the winter-spring cohort of Ommastrephes bartramii in the northwest Pacific.

of the squid-jigging vessels was a reliable indicator of stock abundance on the fishing ground (Chen et al. 2008). The monthly nominal CPUE in one fishing unit of $0.5^{\circ} \times 0.5^{\circ}$ is calculated as follows:

$$
\mathrm{CPUE}_{y m i}=\frac{C_{y m i}}{F_{y m i}}
$$

where $\mathrm{CPUE}_{y m i}$ is monthly CPUE at $i$ fishing unit in month $m$ and year $y ; C_{y m i}$ is monthly catch $(t)$ at $i$ fishing unit in month $m$ and year $y$; and $F_{y m i}$ is number of fishing days at $i$ fishing unit in month $m$ and year $y$.

Because the annual catch of $O$. bartramii by Chinese mainland accounted for about $80 \%$ of the total catches of this species (Cao 2010), we modified the annual total catch of $O$. bartramii from 2003 to 2013 in the northwest Pacific for our estimation (Fig. 1). Although the total annual catch estimated using this approach may have some issues for some years, the focus of this study is to develop and demonstrate a modelling framework which incorporates critical habitat information in the stock assessment for environmentally-sensitive species, and this data set is sufficient to serve this purpose.

\section{Environmental data}

Environmental variables SST, SSH and Chl- $a$ concentration were used to obtain the standardized yearly CPUE based on the generalized additive model (GAM). Monthly SST, SSH and Chl- $a$ concentration data from 2003 to 2013 on the presumed spawning $\left(20^{\circ}-30^{\circ} \mathrm{N}\right.$, $\left.130^{\circ}-170^{\circ} \mathrm{E}\right)$ and fishing grounds $\left(38^{\circ}-46^{\circ} \mathrm{N}, 150^{\circ}\right.$ $165^{\circ} \mathrm{E}$ ) were obtained from the Live Access Server of National Oceanic and Atmospheric Administration OceanWatch (http://oceanwatch.pifsc.noaa.gov/ las/servlets/dataset). The spatial resolution of SST, $\mathrm{SSH}$ and Chl- $a$ concentration data were $0.1^{\circ} \times 0.1^{\circ}$, $0.25^{\circ} \times 0.25^{\circ}$, and $0.05^{\circ} \times 0.05^{\circ}$, respectively. All the environmental data were then converted to a $0.5^{\circ} \times 0.5^{\circ}$ 
grid by the method of averaging for each month in order to correspond to the spatial grid of CPUE. For instance, averaging 25 points of SST can convert to a $0.5^{\circ} \times 0.5^{\circ}$ grid.

\section{Standardizing yearly CPUE by generalized additive model}

CPUE is commonly assumed to be proportional to stock abundance. Therefore, it is usually considered as a relative abundance index in the monitoring and assessment of a fish stock (Maunder and Punt 2004). The GAM model is previously employed to standardize yearly CPUEs, which represent the same proportional change in stock size of $O$. bartramii using data samples (Tian et al. 2009a). The CPUE is naturally lntransformed with errors being assumed to be normally distributed in the GAM modelling. This assumption was evaluated using Q-Q plots. The functional relationships between CPUE and environmental variables are likely to be non-linear (Bigelow et al. 1999). Thus, GAM was used for the CPUE standardization in this study, which can be written as:

$$
\begin{gathered}
\mathrm{Ln}(\mathrm{CPUE}+c)=\text { factor }(\text { year })+\text { factor }(\text { month })+ \\
+s(\text { longitude })+s(\text { latitude })+s(\mathrm{SST})+ \\
+s(\mathrm{SSH})+s(\text { Chl }-a)+\varepsilon
\end{gathered}
$$

where $s$ is a spline smoother function; and constant $c$ is assumed to be $10 \%$ of mean CPUE (Campbell 2004); $\operatorname{var} \varepsilon=\sigma^{2}$ and $E(\varepsilon)=0$.

\section{Environmentally dependent surplus production models}

The areas with the favourable $\operatorname{SST}\left(21-25^{\circ} \mathrm{C}\right)$ in the presumed spawning ground $\left(20^{\circ}-30^{\circ} \mathrm{N}, 130^{\circ}-170^{\circ} \mathrm{E}\right)$ during the spawning season (January-April) play a critical role in determining the recruitment of $O$. bartramii (Saito 1994, Hayase 1995, Bower 1996, Bower and Ichii 2005), and the areas with favourable SST $\left(15^{\circ} \mathrm{C}-19^{\circ} \mathrm{C}\right.$ in August, $14-18^{\circ} \mathrm{C}$ in September, $10-13^{\circ} \mathrm{C}$ in October and $12-15^{\circ} \mathrm{C}$ in November) on the feeding ground $\left(38^{\circ}-46^{\circ} \mathrm{N}, 150^{\circ}-165^{\circ} \mathrm{E}\right)$ during the feeding season (August-November) influence the distribution of $O$. bartramii in feeding activity (Chen 1997, 1999, Chen and Tian 2005). Annual environmental indices were averaged from monthly $P_{\mathrm{s}}$ and $P_{\mathrm{f}}$ which were calculated by the number of fishing units with the optimal SST divided by the total number of the fishing units on the spawning and feeding ground, respectively.

Schaefer's surplus production model (referred to as $\mathrm{SP})$ can be written as

$$
\begin{gathered}
\log \left(B_{t}\right) \mid K, \sigma^{2}=\log (K)+u_{t} \\
\log \left(B_{t}\right) \mid B_{t-1}, K, r, \sigma^{2}= \\
=\log \left\{B_{t-1}+r B_{t-1}\left(1-\frac{B_{t-1}}{K}\right)-C_{t-1}\right\}+u_{t} \\
\log \left(I_{t}\right) \mid B_{t}, q, \tau^{2}=\log (q)+\log \left(B_{t}\right)+v_{t}
\end{gathered}
$$

where $B_{t}$ is the biomass in $t$ year; $K$ is the carrying capacity; $r$ is the intrinsic rate of stock growth; $q$ is the catch ability coefficient; and $I_{t}$ is the CPUE in $t$ year. $I_{t}$ is assumed to be proportional to $B_{t}$, and $u_{t}$ and $v_{t}$ are independent and identically distributed IID $\mathrm{N}\left(0, \sigma^{2}\right)$ and IID $\mathrm{N}\left(0, \tau^{2}\right)$ random variables respectively.

We hypothesized that for a given year "effective" carrying capacity was in proportion to $P_{\mathrm{s}}$ and the "effective" intrinsic stock growth rate changed in proportion to $P_{\mathrm{f}}$ for $O$. bartramii. Therefore, the surplus production model with the parameter of $P_{\mathrm{s}}$ (referred to as $P_{\mathrm{s}}$-EDSP) is given by:

$$
\begin{gathered}
\log \left(B_{t}\right) \mid K, \sigma^{2}=\log (K)+u_{t} \\
\log \left(B_{t}\right) \mid B_{t-1}, K, r, \sigma^{2}= \\
=\log \left\{B_{t-1}+r B_{t-1}\left(1-\frac{B_{t-1}}{P s_{t-1} K}\right)-C_{t-1}\right\}+u_{t}
\end{gathered}
$$

The surplus production model with the parameter of $P_{\mathrm{f}}$ (referred to as $P_{\mathrm{f}}$-EDSP) is given by:

$$
\begin{gathered}
\log \left(B_{t}\right) \mid K, \sigma^{2}=\log (K)+u_{t} \\
\log \left(B_{t}\right) \mid B_{t-1}, K, r, \sigma^{2}= \\
=\log \left\{B_{t-1}+P f_{t-1} r B_{t-1}\left(1-\frac{B_{t-1}}{K}\right)-C_{t-1}\right\}+u_{t}
\end{gathered}
$$

The surplus production model with the parameters of both $P_{\mathrm{s}}$ and $P_{\mathrm{f}}$ (referred to as $P_{\mathrm{s}}-P_{\mathrm{f}}$-EDSP) is given by:

$$
\begin{gathered}
\log \left(B_{t}\right) \mid K, \sigma^{2}=\log (K)+u_{t} \\
\log \left(B_{t}\right) \mid B_{t-1}, K, r, \sigma^{2}= \\
=\log \left\{B_{t-1}+P f_{t-1} r B_{t-1}\left(1-\frac{B_{t-1}}{P s_{t-1} K}\right)-C_{t-1}\right\}+u_{t}
\end{gathered}
$$

Based on the results of Prager (1994) and Chen et al. (2011b), we assumed that the initial biomass of $O$. bartramii $B_{0}$ in 2003 was 400000 t. The likelihood function and prior distribution of the parameters in Bayesian inference were stated as follows:

\section{- Likelihood function}

We fitted Schaefer's surplus production models by Bayesian inference in R using the R2WinBugs library (Sturtz et al. 2005). A likelihood function was used to estimate the degree of fitting between the observation data and the data predicted by the surplus production models ( $\mathrm{Li}$ et al. 2011). We assumed that the observation errors followed the ln-normal distribution, and the likelihood function is written as:

$$
L(I \mid \theta)=\prod_{2003}^{2013} \frac{1}{I_{t} \sigma \sqrt{2 \pi}} \exp \left\{\frac{\left[\log \left(I_{t}\right)-\log \left(q B_{t}\right)\right]^{2}}{2 \sigma^{2}}\right\}
$$

The $\sigma$ was estimated to be 0.12 in the CPUE stanardization. 
Table 1. - The fishery management reference points of $O$. bartramii in the northwest Pacific Ocean. BRP, biological reference point; SP, surplus production; EDSP, environmentally dependent surplus production models; $P_{\mathrm{s}}$, proportion of favourable spawning habitat areas with sea surface temperature of $21-25^{\circ} \mathrm{C} ; P_{\mathrm{f}}$, proportion of favourable feeding habitat areas with different sea surface temperature ranges in different months; MSY, maximum sustainable yield. Note: $C_{t}$ is the catch in year $t$ and $B_{t}$ is the biomass in year $t$

\begin{tabular}{lcc}
\hline Management reference point & Catch & Fishing mortality coefficient $(F)$ \\
BRP in SP model & MSY $=r K / 4$ & $F_{\mathrm{MSY}}=r / 2$ \\
$F_{0.1}=0.45 r$ & $F_{t}=C_{t} / B_{t}$ \\
$F_{\mathrm{MSY}}=P_{\mathrm{f}} r / 2$ & $F_{0.1}=0.45 P_{\mathrm{f}} r$ \\
$F_{t}=C_{t} / B_{t}$
\end{tabular}

\section{- Setting prior distribution of model parameters}

The parameters of $r, K$ and $q$ were assumed to be normally distributed as $\mathrm{N}\left(1.19,0.6^{2}\right), \mathrm{N}\left(75,37.5^{2}\right)$ and $\mathrm{N}\left(1.5 \times 10^{-5},\left(0.75 \times 10^{-5}\right)^{2}\right)$, respectively (Ichii et al. 2006, Cao 2010, Chen et al. 2011b).

\section{- Calculating posterior distribution of parameters}

The initial guess values for the parameters of models in the likelihood estimation were set as follows: the intrinsic rate of growth was 0.8 , carrying capacity was $400000 \mathrm{t}$ and the catchability coefficient was $0.5 \times 10^{-5}$. The posterior distribution of parameters of Schaefer models were calculated by the Markov Chain Monte Carlo (MCMC) method in R. Three MCMC chains were used and the number of MCMC iterations was 50000, and the first 10000 results of iterations were discarded. For the subsequent 40000 times, we saved the results every 40 times.

Fishery biological reference points, including maximum sustainable yield (MSY), fishing mortality at MSY level $\left(F_{\mathrm{MSY}}\right)$, biomass at MSY level ( $\left.B_{\mathrm{MSY}}\right)$, fishing mortality at target level ( $F_{\text {tar }}$, fishing mortality at 0.1 level, $\left.F_{0.1}\right)$, fishing mortality at MSY level $\left(F_{\mathrm{MSY}}\right)$, and actual fishing mortality for year $t\left(F_{t}\right)$ based on the SP and EDSP were estimated using mean values of posterior distribution of parameters of models (Table 1). The selection of models was based on the deviance information criterion (DIC), where the lowest DIC is selected to be the best model.

\section{RESULTS}

\section{Comparing the nominal CPUE with the GAM- standardized CPUE}

The GAM model was constructed based on temporal (year and month), spatial (latitude and longitude) and environmental (SST, SSH and Chl- $a$ concentration) factors. The annual nominal CPUE was then compared with the GAM-estimated standardized CPUE from 2003 to 2013. The same variability trends were exhibited between the annual nominal CPUE and the

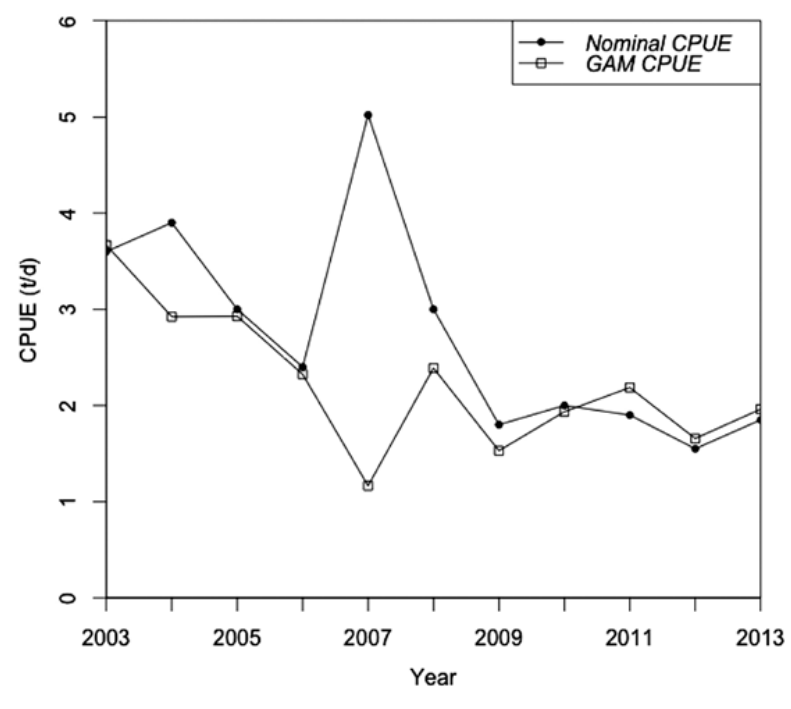

Fig. 2. - Nominal CPUE and GAM-standardized CPUE in 2003-2013.

GAM-standardized CPUE (Fig. 2). Large differences occurred in 2007: the nominal CPUE was highest with a value of $5.12 \mathrm{t} \mathrm{d}^{-1}$, while the GAM-standardized CPUE in 2007 was extremely low with a value of 1.16 $\mathrm{t} \mathrm{d}^{-1}$. The production and abundance of western winterspring cohort of $O$. bartramii fluctuated from year to year: both were high in 2003-2008 and low in 20092013 (Fig. 1).

\section{Comparison of surplus production models}

According to the samplings in MCMC and the posterior distribution of parameters $(r, K$, and $q)$ of the four surplus production models (Fig. 3), there were large differences between the posterior distribution of parameters and their prior distributions. The mean posterior values of parameters $(r, K$, and $q)$ for the four surplus production models were different. The ranges of $r, K$, and $q$ were 1.71-1.90,650000-950000 t, and $0.3-0.4 \times 10^{-5}$, respectively. The minimum values of $r$

Table 2. - Summary statistics for the parameters of Schaefer surplus production models of $O$. bartramii.

\begin{tabular}{|c|c|c|c|c|c|c|c|c|c|c|c|c|c|}
\hline \multirow{3}{*}{ Models } & \multicolumn{13}{|c|}{ Parameters } \\
\hline & \multicolumn{4}{|c|}{$r$} & \multicolumn{4}{|c|}{$K 10^{4}$} & \multicolumn{4}{|c|}{$q 10^{-4}$} & \multirow[t]{2}{*}{ DIC } \\
\hline & Mean & $\mathrm{SD}$ & Rhat & n.eff & Mean & SD & Rhat & n.eff & Mean & $\mathrm{SD}^{1}$ & Rhat & n.eff & \\
\hline SP model & 1.77 & 0.65 & 1.00 & 580 & 65 & 0.17 & 1.00 & 1000 & 0.04 & 0.002 & 1.00 & 1000 & 55.9 \\
\hline$P_{\mathrm{s}}$-model & 1.71 & 0.69 & 1.00 & 1000 & 90 & 0.16 & 1.00 & 1000 & 0.03 & 0.002 & 1.00 & 290 & 30.7 \\
\hline$P_{\mathrm{f}}$-model & 1.90 & 0.78 & 1.00 & 420 & 80 & 0.17 & 1.00 & 1000 & 0.03 & 0.002 & 1.00 & 820 & 35.8 \\
\hline$P_{\mathrm{s}}-P_{\mathrm{f}}$-model & 1.87 & 0.77 & 1.00 & 1000 & 95 & 0.17 & 1.00 & 1000 & 0.03 & 0.002 & 1.00 & 1000 & 40.1 \\
\hline
\end{tabular}



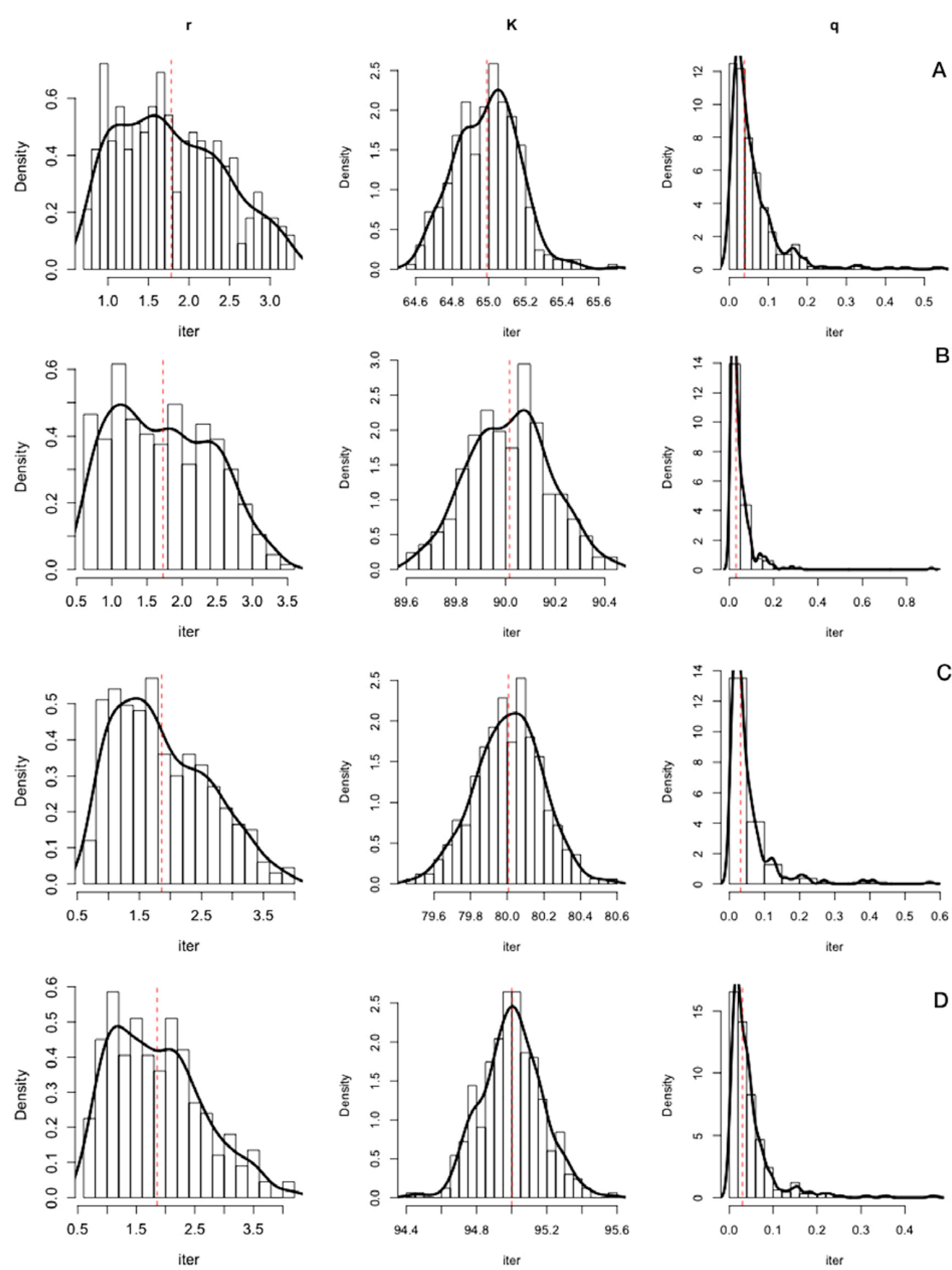

Fig. 3. - Density for $r, K, q$ in (A) the SP model; B, the $P_{\mathrm{s}}$-EDSP model; C, the $P_{\mathrm{f}}$-EDSP model; D, the $P_{\mathrm{s}}-P_{\mathrm{f}}$-EDSP model.

and $K$ occurred in the $P_{\mathrm{s}}$-EDSP and SP model, and the maximum of $r$ and $K$ occurred in the $P_{\mathrm{f}^{-}}$-model and $P_{\mathrm{s}^{-}}$ $P_{\mathrm{f}}$-model, respectively. The results suggested that the optimal fitted model was the $P_{\mathrm{s}}$-EDSP with the minimum DIC value (Table 2).

The MSY and $B_{\mathrm{MSY}}$ were 289100 and $325000 \mathrm{t}$ for the SP model, respectively (Table 3). The MSY varied from 210000 to $262500 \mathrm{t}$ and its biomass ranged from 360000 to 450000 t for the $P_{\mathrm{s}}$-EDSP model (Table 3). For the $P_{\mathrm{f}}$-EDSP model, the MSY ranged from 245300 to $371600 \mathrm{t}$, and the $B_{\mathrm{MSY}}$ was approximately 400000 t (Table 3). For the $P_{\mathrm{s}}-P_{\mathrm{f}}$-EDSP model, the MSY was within the range of 254100 to $392400 \mathrm{t}$, and the $B_{\mathrm{MSY}}$ was from 380000 to $475000 \mathrm{t}$ (Table 3 ).
Moreover, the values of $F_{\text {tar }}$ and $F_{\mathrm{MSY}}$ in the SP model differed from those in other three models (Table 3 ). Of the four surplus production models, the indications were that the fishing mortality coefficient of $O$. bartramii from 2003 to 2013 was much smaller than the values of $F_{\text {tar }}$ and $F_{\mathrm{MSY}}$. Meanwhile, the annual catch of $O$. bartramii in 2003-2013 was also lower than the value of MSY (Table 3).

The results of the four surplus production models indicated that the biomass and development of the $O$. bartramii fishery are in a good state at present (Table 3; Fig. 4). The resource of this species was at a high level, with no sign of occurrence of overfishing based on the $P_{\mathrm{s}}$-EDSP model (Fig. 4). 


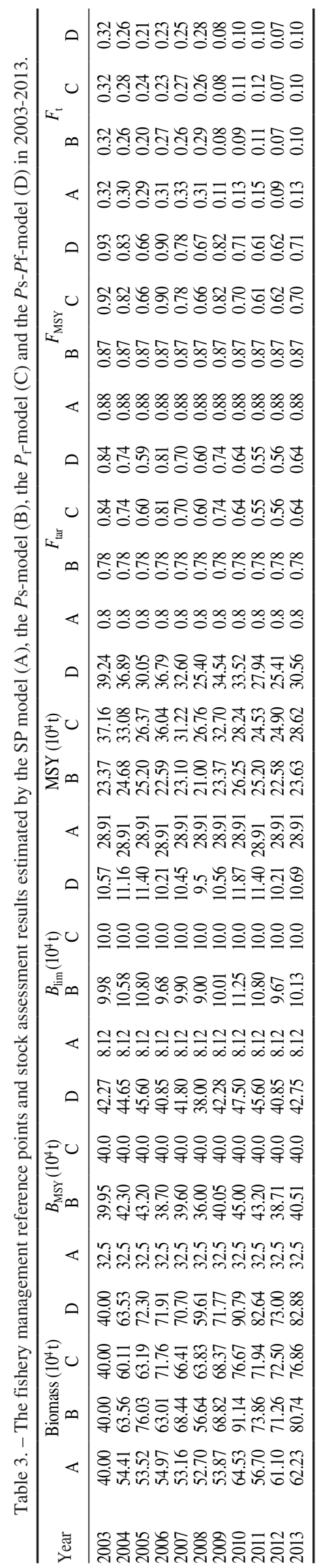

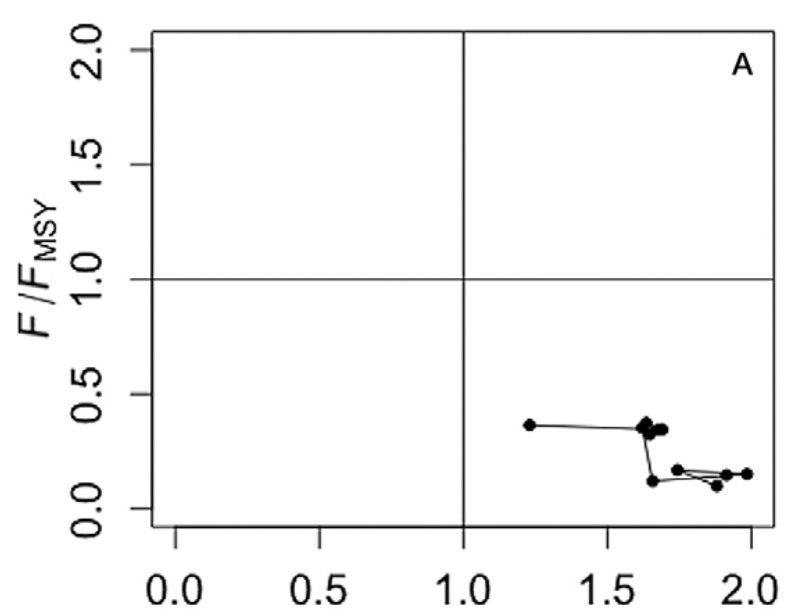

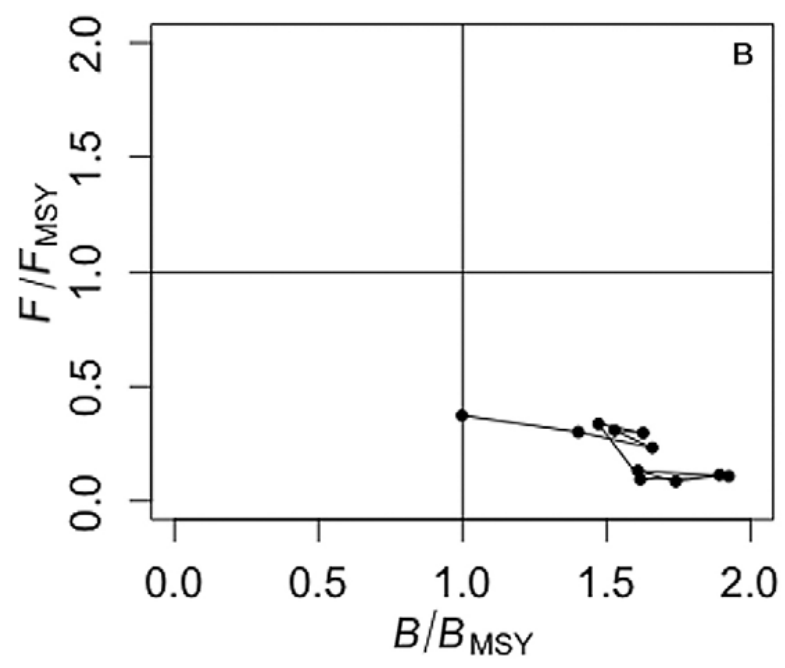

Fig. 4. - Development of the O. bartramii fishery from 2003 to 2013 based on the SP model (A) and the $P_{\mathrm{s}}$-EDSP model (B).

\section{DISCUSSION}

There have been many attempts to explain variation in recruitment based on the relationship between some direct or indirect measures of year-class strength and environmental variables (Cushing 1982). The most commonly used environmental variables are temperature, salinity and wind (Leggett and Frank 2008). Temperature, because it regulates many physiological processes, has been considered to be an important explanatory variable of recruitment in the context of global warming (Cardinale and Hjelm 2006). Salinity has frequently been used as an indirect measure of nutrient flux, and the physical process by which wind may influence recruitment is thought to be primarily through effects on the egg and larval transportation and distribution (Leggett and Frank 2008). The significance of these variables identified in this study is consistent with their ecological roles in regulating the squid habitat quality and stock dynamics (Yu et al. 2015).

For a short-lived species, the role of environmental variables in regulating its population dynamics has received much emphasis and comprises an important research topic (Roberts 1998, Agnew et al. 2002). Most squid live for less than one year (Boyle 1987), and re- 
cruitment success is greatly influenced by the physical and biological environmental conditions on the spawning and nursery grounds, which contribute to the variability in the stock abundance (Sakurai et al. 2000). In addition, the abundance and distribution of squid populations on the fishing ground tend to be greatly affected by oceanographic conditions and respond quickly to changes in the environment (Wadley and Liu 1983, Waluda et al. 1999, 2001, 2006, Yatsu et al. 2000, Anderson and Rodhouse 2001, Rodhouse 2001, Bazzino et al. 2005). For instance, Waluda et al. (2001) suggested that about 55\% of the variability in recruitment of the Falkland Island Illex argentinus fishery could be explained by variations in the total putative favourable SST areas on the spawning ground during the spawning season. Variability in the abundance of Todarodes pacificus in the Sea of Japan was found to be closely related to changes in their favourable SST areas for paralarvae development (Sakurai et al. 2000). Cao et al. (2009) and Cao (2010) suggested that February $P_{\mathrm{s}}$ and August to November $P_{\mathrm{f}}$ could account for about $60 \%$ of the variability in $O$. bartramii abundance between 1995 and 2004. February $P_{\mathrm{s}}$ was the most important factor influencing squid recruitment during the spawning season, and feeding ground $P_{\mathrm{f}}$ during the fishing season also had a strong influence on CPUE. Consequently, the SST is an important environmental indicator for predicting the recruitment of squid (Agnew et al. 2002), and should be considered in O. bartramii stock assessment.

In this study, the nominal CPUE in 2007 was extremely high, possibly due to the high concentrated fishing operation along the longitudinal direction during that year. This finding suggests that it is important to obtain the standardized yearly CPUE. Additionally, no significant correlations were identified between yearly CPUE and monthly $P_{\mathrm{s}}$ and $P_{\mathrm{f}}$. However, Cao et al. (2009) and Cao (2010) evaluated the influences of SST on the spawning ground on the abundance of $O$. bartramii. These authors suggested that there was a significant positive relationship between the monthly proportion of favourable SST areas on the spawning ground and CPUE, but this relationship was not consistent with the results of our study. The reasons which caused this difference might be the use of a variety of resource abundance indicators (nominal or standardized CPUE) and different sources of fishery data. Therefore, the average $P_{\mathrm{s}}$ during spawning months and the average $P_{\mathrm{f}}$ during feeding months other than significant $P_{\mathrm{s}}$ and $P_{\mathrm{f}}$ were used to measure the "effective" $K$ and $r$. The methods for estimating the parameters of the surplus production model can be divided into three types: equilibrium estimators, process-error estimators and observation-error estimators (Polacheck et al. 1993, Wang et al. 2014b). Each estimator has its own drawback. For example, the assumption of the equilibrium estimators is that they are suitable for applying to a fishery in equilibrium but not for an actual fishery. For process-error estimators, we usually obtain negative values of parameters $(r, q)$ when converting the surplus production equation into a linear form fitted by a linear regression. Bayesian inference has been increasingly used for fisheries in recent years because it provides a systematic approach that explicitly incorporates both uncertainty and risk caused by uncertainty in the analysis (Hilborn et al. 1993, McAllister et al. 1994, Kinas 1996, Chen et al. 2000). Atypical errors should also be noted in the data. Mis-specification of prior distribution and the choice of an inappropriate likelihood function may result in unreliable posterior distribution for parameters in Bayesian inference (Berger 1994, Adkison and Peterman 1996, McAllister and Kirkwood 1998, Chen et al. 2000). In this paper, we used Bayesian inference to estimate the parameters of the four surplus production models, and attempted to interpret the data consistently by using standardized CPUE and modifying the yearly catch from 2003 to 2013 . We also referred to some previous studies in order to set the prior distribution (normal distribution) of parameters and to select the likelihood function (Cao 2010, Chen et al. 2011b). According to the MCMC results, there were great differences in the posterior distributions of parameters $(r, K, q)$ and prior distributions. It was shown that the fishery data for $O$. bartramii provided enough information to estimate the parameters in these four surplus production models.

Fishery statistics of the Chinese squid-jigging fleets (Fig. 1) suggest a large fluctuation in annual production of $O$. bartramii. In this study, the annual catches of $O$. bartramii are lower than the MSY. The current fishing mortality rates are also lower than $F_{t a r}$ in the four surplus production models, indicating that overfishing does not occur in the $O$. bartramii fishery (Fig. 4). The yearly biomass of $O$. bartramii in the four surplus production models is higher than $B_{\mathrm{MSY}}$, suggesting that the resource of $O$. bartramii is not overfished and has been at a high level of abundance in recent years. Thus, we can conclude that overfishing does not occur and the stock is not overfished for the $O$. bartramii stock in the northwest Pacific. These findings are basically consistent with the previous results (Cao 2010, Chen et al. 2011b).

The DIC value of the original surplus production model was maximum in the four models, and the fitting level of the surplus production model with environmental factors was higher than that of the models without environmental factors (Table 3 ). Changes in environmental factors $\left(P_{\mathrm{s}}\right.$ and $\left.P_{\mathrm{f}}\right)$ have important impacts on carrying capacity $(K)$ and intrinsic rate of growth $(r)$. The particle-tracking experiment showed that paralarvae and juveniles aged $<90$ days remained on their spawning grounds and that Chl- $a$ in this habitat, where $21^{\circ} \mathrm{C}<\mathrm{SST}<25^{\circ} \mathrm{C}$, had a significant positive correlation with the CPUE (Nishikawa et al. 2014), and $P_{\mathrm{s}}$ calculated by average optimal SST $\left(21^{\circ} \mathrm{C}<\mathrm{SST}<25^{\circ} \mathrm{C}\right)$ on the spawning ground would affect the survival of paralarvae and juveniles. Moreover, SST was the most important environmental factor in the formation of the fishing ground based on the HSI model and the neural network model (Tian et al. 2009b, Wang et al. 2014a). $P_{\mathrm{f}}$ is a measure of habitat quality of the fishing ground and would affect individual growth. Hence, environmental conditions, especially $P_{\mathrm{s}}$ and $P_{\mathrm{f}}$, have significant influences on the spawning, hatching, growth, and even the whole life history of $O$. bartramii. We considered annual variability of environmental variables in estimating fishery management reference points (MRPs), resulting in temporal differences in reference 
points, which better reflect temporal changes in the habitat quality than the reference points assumed to be same over time in a traditional stock assessment. This can be useful to help adjust annual regulations in $O$. bartramii fisheries management.

The development status of the $O$. bartramii fishery from 2003 to 2013 based on the SP model and the $P_{\mathrm{s}}$-EDSP model were plotted (Fig. 4). At present, the $O$. bartramii fishery development is still not fully exploited, and the advantage of the EDSP model is not obvious in this situation. However, with an increased intensity of exploitation, the EDSP model proves to be more conservative as the " $B / B_{\mathrm{MSY}}$ " in the $P_{\mathrm{s}}$-EDSP model tended to be closer to " 1 " (the threshold of overfishing) than that in the SP model (Fig. 4). In summary, when there was low $P_{\mathrm{s}}$ and $P_{\mathrm{f}}$, the "effective" $r$ and $K$ decreased, calling for a decline in fishing effort to avoid the overexploitation of $O$. bartramii resources.

The uncertainty of the models came mainly from (1) uncertainty associated with data because we only included the catch data from the Chinese fishery, although we standardized yearly CPUE and modified yearly catches; and (2) uncertainty of model parameters: we assumed the biomass in 2003 to be an initial value of $400000 \mathrm{t}$, and this may induce biases in the estimation of biomass of $O$. bartramii. In addition, we also assumed that the standard deviation of CPUE $(\sigma)$ was equal to 0.12 , and the effects of this assumed $\sigma$ value on model selection and resource assessment need to be further investigated in future studies.

In summary, an estimated EDSP model fitted the data better than the conventional Schaefer surplus model without environmental factors in estimating the squid stocks. We found that the fishery MRPs largely depended on optimal spawning and feeding habitat areas. These findings suggest that environmental factors on the spawning and feeding grounds should be considered in squid stock assessment and management of $O$. bartramii in the northwest Pacific.

\section{ACKNOWLEDGEMENTS}

We thank the Chinese Distant-Water Squid-Jigging Technical Group for providing fishery data and information, and we thank NOAA for providing the environmental data used in this paper. This work was funded by State 863 projects (2012AA092303), the Funding Programme for Outstanding Dissertations at Shanghai Ocean University, the Funding Scheme for Training Young Teachers in Shanghai Colleges and the Shanghai Leading Academic Discipline Project (Fisheries Discipline). Involvement of Y. Chen was supported by SHOU International Centre for Marine Studies and the Shanghai 1000 Talent Programme.

\section{REFERENCES}

Adkison M.D., Peterman R.M. 1996. Results of Bayesian methods depend on details of implementation: an example of estimating salmon escapement goals. Fish. Res. 25: 155-170. http://dx.doi.org/10.1016/0165-7836(95)00405-X

Agnew D.J., Beddington J.R., Hill S.L. 2002. The potential use of environmental information to manage squid stocks. Can. J.
Fish. Aquat. Sci. 59: 1851-1857. http://dx.doi.org/10.1139/f02-150

Anderson C.I.H., Rodhouse P.G. 2001. Life cycles, oceanography and variability: ommastrephid squid in variable oceanographic environments. Fish. Res. 54: 133-143.

http://dx.doi.org/10.1016/S0165-7836(01)00378-2

Bazzino G., Quiñones R.A., Norbis W. 2005. Environmental associations of shortfin squid Illex argentinus (Cephalopoda: Ommastrephidae) in the Northern Patagonian Shelf. Fish. Res. 76: $401-416$ http://dx.doi.org/10.1016/j.fishres.2005.07.005

Berger J.O., Moreno E., Pericchi LR, et al. 1994. An overview of robust Bayesian analysis. Test. 3(1): 5-124. http://dx.doi.org/10.1007/BF02562676

Bigelow K.A., Boggs C.H., He X.I. 1999. Environmental effects on swordfish and blue shark catch rates in the US North Pacific longline fishery. Fish. Oceanogr. 8: 178-198. http://dx.doi.org/10.1046/j.1365-2419.1999.00105.x

Bower J.R. 1996. Estimated paralarval drift and inferred hatching sites for Ommastrephes bartramii (Cephalopoda: Ommastrephidae) near the Hawaiian Archipelago. Fish. Bull. 94: 398-411.

Bower J.R., Ichii T. 2005. The red flying squid (Ommastrephes bartramii): A review of recent research and the fishery in Japan. Fish. Res. 76: 39-55. http://dx.doi.org/10.1016/j.fishres.2005.05.009

Boyle P.R. (ed) 1987. Cephalopod life cycles. Vol. II. Comparative reviews. Academic Press, London, $441 \mathrm{pp}$.

Campbell R.A. 2004. CPUE standardization and the construction of indices of stock abundance in a spatially varying fishery using general linear models. Fish. Res. 70: 209-227. http://dx.doi.org/10.1016/j.fishres.2004.08.026

Cao J. 2010. Stock assessment and risk analysis of management strategies for neno flying squid (Ommastrephes bartramii) in the Northwest Pacific Ocean. Shanghai Ocean University.

Cao J., Chen X.J., Chen Y. 2009. Influence of Surface Oceanographic Variability on Abundance of the Western WinterSpring Cohort of Neon Flying Squid Ommastrephes bartramii in the New Pacific Ocean. Mar. Ecol. Prog. Ser. 381: 119-127. http://dx.doi.org/10.3354/meps07969

Cardinale M., Hjelm J. 2006. Marine fish recruitment variability and climate indices. Mar. Ecol. Prog. Ser. 309: 307-309.

Chen X.J. 1997. An analysis on marine environment factors of fishing grounds of Ommastrephes bartramii in Northwest Pacific. J. Shanghai Fish. Univ. 6: 285-287.

Chen X.J. 1999. Study on the formation of fishing grounds of the large squid, Ommastrephes bartramii in the waters $160^{\circ} \mathrm{E}$ $170^{\circ}$ E North Pacific Ocean. J. Shanghai Fish. Univ. 8: 197-201.

Chen X.J., Tian S.Q. 2005. Study on the catch distribution and relationship between fishing grounds and surface temperature for Ommastrephes bartramii in the Northwestern Pacific Ocean. Period. Ocean Univ. China. 35: 101-107.

Chen Y., Breen P.A., Andrew N.L. 2000.Impacts of outliers and mis-specification of priors on Bayesian fisheries-stock assessment. Can. J. Fish. Aquat. Sci. 57: 2293-2305. http://dx.doi.org/10.1139/f00-208

Chen X.J., Zhao X.H., Chen Y. 2007. Influence of El Niño/La Niña on the western winter-spring cohort of neon flying squid $(\mathrm{Om}$ mastrephes bartramii) in the northwestern Pacific Ocean. ICES J. Mar. Sci. 64: 1152-1160.

Chen X.J., Chen Y., Tian S.Q., et al. 2008.An assessment of the west winter-spring cohort of neon flying squid (Ommastrephes bartramii) in the Northwest Pacific Ocean. Fish. Res. 92: 221-230. http://dx.doi.org/10.1016/j.fishres.2008.01.011

Chen X. J., Tian S. Q., Liu B. L., et al. 2011a. Modelling of Habitat suitability index of Ommastrephes bartramii during June to July in the central waters of North Pacific Ocean. Chinese J. Oceanol. Limnol. 29(3): 493-504. http://dx.doi.org/10.1007/s00343-011-0058-y

Chen X.J., Cao J., Liu B.L., et al. 2011b. Stock assessment and management of Ommastrephes bartramii by using a Bayesian Schaefer model in Northwestern Pacific Ocean. J. Fish. China. 35: 1572-1581.

Cushing D.H. 1982. Climate and Fisheries. London, Academic Press.

Hayase S. 1995. Distribution of spawning grounds of flying squid, Ommastrephes bartramii, in the North Pacific Ocean. Jpn. Agric. Res. Q. 29: 65-72.

Hikaru W., Tsunemi K.,Taro I., et al. 2004. Feeding habits of neon flying squid Ommastrephes bartramii in the transitional region of the central North Pacific. Mar. Ecol. Prog. Ser. 266: 173-184. http://dx.doi.org/10.3354/meps266173 
Hilborn R., Walters C.J. 1992. Quantitative fisheries stock assessment: choice, dynamics and uncertainty. Springer Science \& Business Media. http://dx.doi.org/10.1007/978-1-4615-3598-0

Hilborn R., Pikitch E.K., Francis R.C. 1993. Current Trends in Including Risk and Uncertainty in Stock Assessment and Harvest Decisions. Can. J. Fish. Aquat. Sci. 50: 874-880. http://dx.doi.org/10.1139/f93-100

Ichii T., Mahapatra K. 2004. Stock assessment of the autumn cohort of neon flying squid (Ommastrephes bartramii) in the North Pacific based on the past driftnet fishery data. Report of the 2004 Meeting on Squid Resources. Japan Sea National Fisheries Research Institute, Niigata, 21-34 pp. (in Japanese).

Ichii T., Mahapatra K., Okamura H., et al. 2006. Stock assessment of the autumn cohort of neon flying squid (Ommastrephes bartramii) in the North Pacific based on past large-scale high seas driftnet fishery data. Fish. Res. 78: 286-297. http://dx.doi.org/10.1016/j.fishres.2006.01.003

Jereb P., Roper C.F.E. (eds). 2010. Cephalopods of the world An annotated and illustrated catalogue of cephalopod species known to date. Volume 2. Myopsid and Oegopsid Squids. FAO Species Catalogue for Fishery Purposes. No. 4, Vol. 2. Rome, FAO, $605 \mathrm{pp}$.

Kinas P.G. 1996. Bayesian fishery stock assessment and decision making using adaptive importance sampling. Can. J. Fish. Aquat. Sci. 53: 414-423. http://dx.doi.org/10.1139/f95-189

Leggett W.C., Frank K.T. 2008. Paradigms in fisheries oceanography. Oceanogr. Mar. Biol. Ann. Rev. 46: 331-364. http://dx.doi.org/10.1201/9781420065756.ch8

Li G., Chen X.J., Guan W.J. 2011. Stock assessment and management for Mackerel in East Yellow Sea. Ocean Press, Beijing, pp. 4-128.

Ludwing D., Walters C.J. 1985. Are age-structured models appropriate for catch-effort data? Can. J. Fish. Aquat. Sci. 42(6): 1066-1072. http://dx.doi.org/10.1139/f85-132

Ludwing D., Walters C.J. 1989. A robust method for parameter estimation from Catch and effort data. Can. J. Fish. Aquat. Sci. 46(1): 137-144. http://dx.doi.org/10.1139/f89-018

Maunder M.N., Punt A.E. 2004. Standardizing catch and effort data: a review of recent approaches. Fish. Res. 70: 141-159. http://dx.doi.org/10.1016/j.fishres.2004.08.002

McAllister M.K., Kirkwood G.P. 1998. Bayesian stock assessment: a review and example application using the logistic model. ICES J. Mar. Sci. 55: 1031-1060. http://dx.doi.org/10.1006/jmsc.1998.0425

McAllister M.K., Pikitch E.K., Punt A.E., et al. 1994. A Bayesian Approach to Stock Assessment and Harvest Decisions Using the Sampling/Importance Resampling Algorithm. Can. J. Fish. Aquat. Sci. 51: 2673-2687. http://dx.doi.org/10.1139/f94-267

Murata M., Nakamura Y. 1998. Seasonal migration and diel vertical migration of the neon flying squid, Ommastrephes bartramii, in the North Pacific. In: Okutani T., (ed) Contributed Papers to International Symposium on Large Pelagic Squids. Japan Mar. Fish. Resources Res. Center, Tokyo, 269 pp.

Nishikawa H., Igarashi H., Ishikawa Y. 2014. Impact of paralarvae and juveniles feeding environment on the neon flying squid (Ommastrephes bartramii) winter-spring cohort stock. Fish. Oceanog., 23(4): 289-303. http://dx.doi.org/10.1111/fog. 12064

Osako M., Murata M. 1983. Stock assessment of cephalopod resources in the northwestern Pacific. In: Caddy J.F. (ed.), Advances in Assessment of World Cephalopod Resources. FAO Fish. Tech. paper No. 231, pp. 55-144.

Polacheck T., Hilborn R., Punt A.E. 1993. Fitting Surplus Production Models: Comparing Methods and Measuring Uncertainty. Can. J. Fish. Aquat. Sci. 50: 2597-2607. http://dx.doi.org/10.1139/f93-284

Prager M.H. 1994. A suite of extensions to a non-equilibrium surplus-production model. Fish. Bull. 92: 374-389.

Roberts M.J. 1998. The influence of the environment on chokka squid Loligo vulgaris reynaudii spawning aggregations: steps towards a quantified model. S. Afr. J. Mar. Sci. 20: 267-284. http://dx.doi.org/10.2989/025776198784126223

Rodhouse P.G. 2001.Managing and forecasting squid fisheries in variable environments. Fish. Res. 54: 3-8. http://dx.doi.org/10.1016/S0165-7836(01)00370-8
Roper C.F.E., Sweeney M.J., Nauen C.E. 1984. FAO species catalogue: An annotated and illustrated catalogue of species of interest to fisheries. FAO Fisheries Synopsis, Cephalopods of the World, Vol. 3(125): 277 pp.

Sakurai Y., Kiyofuji H., Saitoh S., et al. 2000. Changes in inferred spawning areas of Todarodes pacificus (Cephalopoda: Ommastrephidae) due to changing environmental conditions. ICES J. Mar. Sci. 57: 24-30. http://dx.doi.org/10.1006/jmsc.2000.0667

Saito K. 1994. Distribution of paralarvae of Ommastrephes bartramii and Eucleoteuthis luminosa in the eastern waters off Ogasawara Islands. Bull. Hokkaido Natl. Fish. Res. Inst. 58: $15-23$.

Sturtz S., Ligges U., Gelman A. 2005. R2WinBUGS: A Package for Running WinBUGS from R. J. Stat. Soft., 12(3): 1-16. http://dx.doi.org/10.18637/jss.v012.i03

Tian S.Q., Chen X.J., Chen Y., et al. 2009a. Standardizing CPUE of Ommastrephes bartramii for Chinese squid-jigging fishery in Northwest Pacific Ocean. Chin. J. Oceanol. Limnol. 27: 729-739. http://dx.doi.org/10.1007/s00343-009-9199-7

Tian S. Q., Chen X. J., Chen Y., et al. 2009b. Evaluating habitat suitability indices derived from CPUE and fishing effort data for Ommatrephes bratramii in the northwestern Pacific Ocean. Fish. Res. 95(2-3): 181-188. http://dx.doi.org/10.1016/j.fishres.2008.08.012

Wadley V.A., Lu C.C. 1983. Distribution of mesopelagic cephalopods around a warm-core ring in the East Australian Current. Mem. Natl. Mus. Vic. 44: 197-198.

Waluda C.M., Trathan P.N., Rodhouse P.G. 1999. Influence of oceanographic variability on recruitment in the genus Illex argentinus (Cephalopoda: Ommastraphidae) fishery in the South Atlantic. Mar. Ecol. Prog. Ser. 183: 159-167. http://dx.doi.org/10.3354/meps 183159

Waluda C., Rodhouse P., Podestá G., et al. 2001. Surface oceanography of the inferred hatching grounds of Illex argentinus (Cephalopoda: Ommastrephidae) and influences on recruitment variability. Mar. Biol. 139: 671-679. http://dx.doi.org/10.1007/s002270100615

Waluda C.M., Yamashiro C., Rodhouse P.G. 2006. Influence of the ENSO cycle on the light-fishery for Dosidicus gigas in the Peru Current: An analysis of remotely sensed data. Fish. Res. 79: 56-63. http://dx.doi.org/10.1016/j.fishres.2006.02.017

Wang J.T., Chen X.J., Lei L., et al. 2014a. Comparison between two forecasting models of fishing ground based on frequency statistic and neural network for Ommastrephes bartramii in the North Pacific Ocean. J. Guangdong Ocean Univ. 34(3): 82-88.

Wang S.P., Maunder M.N., Aires-da-Silva A. 2014b. Selectivity's distortion of the production function and its influence on management advice from surplus production models. Fish. Res. 158: $181-193$ http://dx.doi.org/10.1016/j.fishres.2014.01.017

Wang Y.G., Chen X.J. 2005.The resource and biology of economic oceanic squid in the world. Ocean Press, Beijing, pp. 79-295.

Yatsu A., Mori J. 2000. Early growth of the autumn cohort of neon flying squid, Ommastrephes bartramii, in the North Pacific Ocean. Fish. Res. 45: 189-194. http://dx.doi.org/10.1016/S0165-7836(99)00112-5

Yatsu A., Watanabe T. 1996. Interannual variability in neon flying squid abundance and oceanographic conditions in the central North Pacific, 1982-1992. Bull. Nat. Res. Inst. Far Seas Fish. 33: 123-138.

Yatsu A., Watanabe T., Mori J., et al. 2000. Interannual variability in stock abundance of the neon flying squid, Ommastrephes bartramii, in the North Pacific Ocean during 1979-1998: impact of driftnet fishing and oceanographic conditions. Fish. Oceanogr. 9: 163-170 http://dx.doi.org/10.1046/j.1365-2419.2000.00130.x

Yu W., Chen X.J., Yi Q., et al. 2013. Review on the early life history of neon flying squid Ommastrephes bartramii in the North Pacific. J. Shanghai Ocean Univ. 22: 755-762.

Yu W., Chen X.J., Yi Q., et al. 2015. Variability of Suitable Habitat of Western Winter-Spring Cohort for Neon Flying Squid in the Northwest Pacific under Anomalous Environments. PLoS One 10(4): e122997. http://dx.doi.org/10.1371/journal.pone.0122997

Zhan B.Y. 1992. Fisheries stock assessment. China Agriculture Press, Beijing, pp. 167-193. 